第 Springer

Kew/

PLANTS PEOPLE

POSSIBILITIES

\title{
Jeffersonia and Plagiorhegma
}

\section{Author(s): J. Hutchinson}

Source: Bulletin of Miscellaneous Information (Royal Botanic Gardens, Kew), Vol. 1920, No. 7 (1920), pp. 242-245

Published by: Springer on behalf of Royal Botanic Gardens, Kew

Stable URL: http://www.jstor.org/stable/4107483

Accessed: 27-06-2016 13:25 UTC

Your use of the JSTOR archive indicates your acceptance of the Terms \& Conditions of Use, available at

http://about.jstor.org/terms

JSTOR is a not-for-profit service that helps scholars, researchers, and students discover, use, and build upon a wide range of content in a trusted digital archive. We use information technology and tools to increase productivity and facilitate new forms of scholarship. For more information about JSTOR, please contact support@jstor.org.

Springer, Royal Botanic Gardens, Kew are collaborating with JSTOR to digitize, preserve and extend access to Bulletin of Miscellaneous Information (Royal Botanic Gardens, Kew) 
leaves $1277 \mathrm{C}$ of the Catalogue with the Rishikunda* label and allows one field label for each of the sheets enumerated in the catalogue, whilst at the same time it makes Wallich's naming consistent. The confusion arose evidently, like many similar cases, when the distribution sets were made up. Sheet " 1278 , i." is quoted in the catalogue under "Sphaerosacme Rohituka, Wall.; Andersonia Rohituka, Roxb." This Sphaerosacme Rohituka, Wall., is really Amoora cucullata, and the quotation is correct as far as the detached large inflorescence of that sheet (left-hand bottom corner) is concerned. Otherwise it represents, as stated above, Sphaerosacme spectabilis, Wall. = Amoora spectabilis, Miq.

I may add that the tree of Amoora spectabilis in the Botanic Garden at Calcutta, from which Wallich took specimens in 1824, was most probably introduced there in 1808 when Hamilton stayed at Goalpara. Wallich's uncertainty as to the Roxburghian species of Andersonia is easy to understand. Although they are mentioned already in Hortus Bengalensis, 1811, they were then still undescribed. It was not until 1832 that the descriptions which Roxburgh drew up subsequently were published in Wallich's edition of Roxburgh's Flora Indica.

Whilst writing this note I came across a very fine drawing of Amoora spectabilis ( $A$. Wallichii), in our collection of drawings. It is no. 351 of a set which was taken over from the East India Museum, and marked on receipt, "Royle, Carey \& others." It is witten up on the back, "Sphaerosacme spectabilis, Wall. Aglaia? Milnex?" and then, written at a later date, "This belongs to Roxburgh's Andersonia, which has since been superseded.' All this is in Wallich's handwriting. On the front, there is written against 351 "Sphaerosacme spectabilis, Wall.," in Royle's hand. There is then no doubt as to what Wallich meant by Sphaerosacme spectabilis, namely the plant you are dealing with. Royle helped Wallich with cataloguing, and that may be how he got connected with the drawing, which is most probably one of Wallich's own collection. Unfortunately our list of Wallich's drawings breaks off with no. 208, after which there are only few entries with very much higher numbers (up to 835$)$.

\section{XXXVII.-JEFFERSONIA AND PLAGIORHEGMA.}

\section{J. HUTCHINSON.}

In the Genera Plantarum, vol. i. p. 44, Bentham and Hooker united the genera Jeffersonia, Bart., and Plagiorhegma, Maxim., from the Eastern United States and North-East Asia, respectively. In making this reduction they remark:-

"Plagiorhegma, Maxim. Prim. Fl. Amur. 34, t. 1, $\dagger$ species Mantchuriensis, ex habitu et fructu certe Jeffersoniae diphyllae congener videtur. Flores adhuc ignoti, illi enim quos auctor dilapsos invenit descripsitque, ipso fatente abnormes erant."

* Rendered Rohilkund in the catalogue which is clearly an error. Hamilton was in Monghyr in 1811, and Rishikunda is near Monghyr.

+ Should be tab. II. 
It is true that Maximowicz had only a fruiting specimen before him when he described Plagiorhegma, and, in failing to discover any trace of stamens, he came to the erroneous conclusion that the flowers were unisexual. But I can see no reason for the statement that the flowers were abnormal. Maximowicz's figure is an excellent one and depicts $P$. dubia just like his type specimen, and as the plant grows in the Rock Garden at Kew. Subsequently flowering specimens were gathered in North-East China by John Ross, and were received at Kew in 1877, an additional specimen being received from the Petrograd herbarium in 1910. On dissecting these I find good differences in the flowers, as well as in the leaves and fruits as noted by Maximowicz. These differences are shown in the following table :-

Jeffersonia, Bart.

Leaves bifoliolate (fig. A). Sepals 4. Petals 8. Stamens 8. Capsule (fig. B) opening by a horizontal slit near the apex (half circumscissile).

Native of the Atlantic States of North America, in woods, Eastern Pennsylvania, New York and Ontario to Wisconsin, Iowa, Virginia and Tennessee, ascending to $2500 \mathrm{ft}$. in Virginia.

\section{Plagiorhegma, Maxim.}

Leaves unifoliolate (figs. C. and D). Sepals 3. Petals 6. Stamens 6. Capsule (fig. E) opening by an oblique and almost verticall slit extending from near the style to almost the base of the capsule.

Native of North-Eastern Asia, from Shengking Province (China) and Corea to the Amur River.

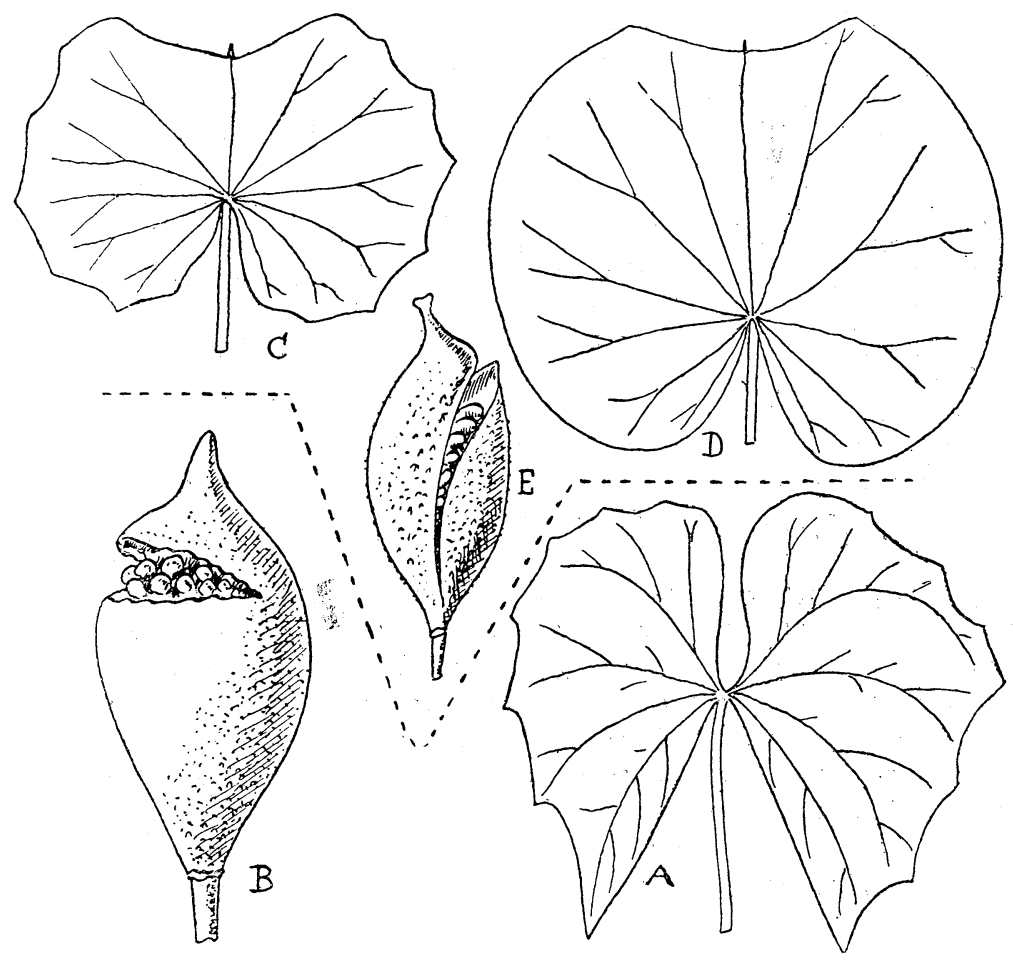

A and B, leaf and fruit of Jeffersonia diphylla; C, D, E, leavesland fruit of Plagiorhegma dubia. 
These three important differences in the leaves, flowers and fruits, coupled with the separate geographical distribution, seem quite adequate for the re-establishment of Plagiorhegma as a valid genus. Bentham and Hooker no doubt paid little attention to the difference in the distribution because of the analogous cases in other genera of Berberidaceae,* some of which show a close relationship and ancient connection between the floras of NorthEastern Asia and North America, especially Atlantic North America. The following genera or species of Berberidaceae are common to these two areas :-

Podophyllum $(P$. peltatum in Canada and E. Un. States; five species in China and Himalaya).

Diphylleia $(D$. cymosa, high altitudes, Virginia to Georgia and Tennessee, and in Central and Western China; D. Grayi in Japan).

Achyls (Pacific N. Amer. and Japan; 2 very closely allied species, A. triphylla, DC., and A. japonica, Maxim., respectively).

Caulophyllum (C. thalictroides, Atlantic N. Amer. and N.E. Asia and Central China).

I give below a revised description of the genus and single species of Plagiorhegma.

Plagiorhegma, Maxim. Prim. Fl. Amur. 34, t. 2 (1859); descr. emend.

Herba polycephala, rhizomate perenni tenui suberecto foliorum basibus vaginantibus membranaceis costatis persistentibus induto. Folia radicalia, unifoliolata, longe petiolata, apice leviter et late biloba, basi cordata, palminervia. Scapus nudus, uniflorus. Sepala 3, petaloidea, mox decidua. Petala 6, plana, sepalis multo majora. Stamina 6, libera; antherae extrorsae, valvulis 2 sursum dehiscentes. Ovarium sessile, stylo brevissimo crasso in stigma cupularem undulate lobatum dilatato; ovula numerosa, ad ventrem circiter 5-6-seriata, adscendentia, anatropa. Capsula parva, coriacea, ab apice fere usque ad basin oblique dehiscens. Semina breviter arillata, arillo carnoso demum lacerato.

P. dubia, Maxim. l.c.

Jeffersonia dubia, Benth. et Hook. f. ex Baker et Moore in Journ. Linn. Soc. xvii. 377 (1879); Gard. Chron. Ixiii. 149, fig. 68 (1918). J. manchuriensis, Hance in Journ. Bot. ix. 258 (1880).

$H e r b a$ perennis fructifera usque ad $30 \mathrm{~cm}$. alta; rhizoma tenue, suberectum, radicalibus fibrosis numerosis instructum, foliorum basibus vaginantibus membranaceis arcte indutum. Folia numerosa, longe petiolata, subreniformia, basi cordata, apice late bilobata, subanthesi circiter $3 \mathrm{~cm}$. diametro et marginibus undulato-lobulata, maturitate multo majora et fere integra (minute denticulata), usque ad $10 \mathrm{~cm}$. diametro, palmatim 9-10-nervia, nervis utrinque conspicuis multiramosis; petioli straminei, sulcati, glabri. Pedunculi floriferi 9-12 cm. longi,

* Excluding Lardizabalaceae, a distinct family included by Bentham and Hooker in the Berberidaceae. 
fructiferi usque ad $20 \mathrm{~cm}$. longi, sulcati, glabri. Sepala 3, petaloidea, mox decidua, oblongo-lanceolata, subobtusa, circiter $6.5 \mathrm{~mm}$. longa, striata, glabra. Petala 6 , obovata, $1 \mathrm{~cm}$. longa, $6 \mathrm{~mm}$. lata, ad basin angustata. Stamina 6, ovario aequilonga; filamenta complanata, $2 \mathrm{~mm}$. longa; antherae $4 \mathrm{~mm}$. longae. Ovarium $4 \mathrm{~mm}$. longum, glabrum; stylus crassus, fere $2 \mathrm{~mm}$. longus, in stigma cupularem undulate lobatum expanso. Capsula $1.4 \mathrm{~cm}$. longa, carnosa, extra rugulosa, stylo persistente $3 \mathrm{~mm}$. longo coronata. Semina brunnea, obovoidea, $3 \mathrm{~mm}$. longa.

Manchuria: Lower Amur River, in pine forests near Pachale, fr., Maximowicz; near Vladivostok, fls., Palczevsky in Herb. Komarov 734. Corea: Chemulpo, fr., Carles 68. Shengking Province : shady wood, Fungshan, fls., Ross 29; wooded valleys, Corean Gate, fr., Ross. Mukden to Yaloo River, near Laoling, fls., Webster 136.

Vernacular name in Manchuria, Kámbalta.

Hance (see above) proposed the new name manchuriensis for dubia, because of the latter's unsuitability; a course, however, which we are unable to follow. For such a trivial reason the changing of specific names would have no end.

\section{XXXVIII.-DECADES KEWENSES}

\section{Plantarum Novarum in Herbario Horti Regit Conservatarum. \\ DECAS XCIX.}

981. Xanthophyllum Burkilli, Drummond et Dunn [Polygalaceae]; e speciebus adhuc cognitis vix ulli arcte affinis, floris magnitudine et structura ad X. Schortechini, King, aliquanto approximata ab ea ob filamenta pilosa, ovarium vix longe-stipitatum, folia chartacea aliasque notas facile distincta.

Arbor modicae altitudinis, ramis irregulariter flexuosis, cortice cinereo-albido. Folia lanceolata, ovato-oblonga vel elliptica, basi cuneata vel subrotundata, versus apicem subito acuminata, apice subobtusa, basi obscure quinquenervia, omnino glabra, superne virentia, subtus glaucescentia, duobus nervis marginalibus marginem subcrassam formantibus, lateralibus ad decem intra marginem anastomosantibus conspicuis pallidis, petiolis coloratis circa $7 \mathrm{~mm}$. longis suffulta. Flores usque ad $1.6 \mathrm{~cm}$. longi, in racemos cernuos circa $3.5 \mathrm{~cm}$. longos paniculatim confertos dispositi; pedicelli puberuli, bracteolis cymbiformibus basalibus apice villosis circa $1.5 \mathrm{~mm}$. longis muniti. Sepala 5 , imbricata, inaequalia, pubescentia, posticum quam alia conspicue majus. Petala 5, omnia fere longitudine aequalia, sepalis 3-plo longiora, vix unguiculata, dorso carinata, carina versus basin angustata. Filamenta basi dilatata, pilosa, duo cum alis inferne connata, tertia petalo superiore plus minus adhaerens, caetera libera, stamina ad basin connectivi pilis satis longis ornata. Discus patelliformis, margine crenato. Ovarium distincte stipitatum, obverse turbinatum, sericeo-pubescens; stylus circa $3 \mathrm{~mm}$. longus, subulatus, pilis sericeis instructus; stigma capitatum; 